\title{
Gender Roles in Sourcing and Sharing of Banana Planting Material in Communities with and without Banana Bunchy Top Disease in Nigeria
}

\author{
Lilian Nkengla-Asi ${ }^{1,2, *}$, Favour Eforuoku ${ }^{1}$, Olamide Olaosebikan ${ }^{1}{ }^{1}$, Temitope Adejoju Ladigbolu ${ }^{1}$, \\ Delphine Amah ${ }^{1}$, Rachid Hanna ${ }^{2} \mathbb{D}$ and P. Lava Kumar ${ }^{1}$ \\ 1 International Institute of Tropical Agriculture (IITA), PMB 5320, Oyo Road, Ibadan PMB5320, Nigeria; \\ favouriteeforuoku@gmail.com (F.E.); D.OLAOSEBIKAN@cgiar.org (O.O.); \\ adejojutemitope@gmail.com (T.A.L.); d.amah@cgiar.org (D.A.); L.kumar@cgiar.org (P.L.K.) \\ 2 International Institute of Tropical Agriculture (IITA), PO Box 2008 Messa, Yaoundé, Cameroon; \\ rachidhanna01@gmail.com \\ * Correspondence: lilian.nkengla@oxfam.org
}

\section{check for}

updates

Citation: Nkengla-Asi, L.; Eforuoku, F.; Olaosebikan, O.; Adejoju

Ladigbolu, T.; Amah, D.; Hanna, R.;

Kumar, P.L. Gender Roles in Sourcing and Sharing of Banana Planting Material in Communities with and without Banana Bunchy Top Disease in Nigeria. Sustainability 2021, 13, 3310. https://doi.org/10.3390/ su13063310

Academic Editor: Pratyusha Basu

Received: 23 December 2020

Accepted: 8 March 2021

Published: 17 March 2021

Publisher's Note: MDPI stays neutral with regard to jurisdictional claims in published maps and institutional affiliations.

Copyright: (c) 2021 by the authors. Licensee MDPI, Basel, Switzerland. This article is an open access article distributed under the terms and conditions of the Creative Commons Attribution (CC BY) license (https:/ / creativecommons.org/licenses/by/ $4.0 /)$.

\begin{abstract}
Banana bunchy top disease (BBTD) is the most devastating disease of banana and plantain (Musa spp.). The disease spreads through the use of infected vegetative propagules and the banana aphid (Pentalonia nigronervosa) is the virus vector. This study seeks to understand the gender dimensions and sociocultural aspects of banana seed (vegetative propagule) sourcing and sharing practices among men and women farmers, and its influence on BBTD spread and disease control efforts. Data were collected from 300 banana farmers (187 men and 113 women) in BBTD and non-BBTD areas in southwest Nigeria. The results revealed that seed sharing within the communities is a social responsibility with members expected to share banana seed with the needy mainly as gifts rather than sold for cash. Men farmers mostly sourced seed from old fields, while women sourced seed from relatives. Harvesting of banana seed was predominantly the responsibility of men with women as helpers. Both men and women farmers in the non-BBTD area cultivated larger farm sizes and harvested more banana planting material than farmers in the BBTD area. The existing seed sourcing practices among men and women farmers heighten the risk of BBTD spread. Awareness raising on disease spread through infected seeds should consider gender-differentiated roles and social practices to reduce its spread within communities.
\end{abstract}

Keywords: seed systems; gender; banana bunchy top virus; disease control; vegetative propagation

\section{Introduction}

Seeds, including botanic seeds and vegetative propagules, are indispensable agricultural inputs that are central to food production, biodiversity conservation, and overall crop yield [1-3]. Seed quality and genetics alone account for at least $15 \%$ of crop productivity, but often much more [4]. Seeds can carry plant pathogens and serve as vehicles for pathogen spread, naturally and through formal and informal seed distribution, from one season to the next, and within and between geographies [5]. The risk of pathogen spread is much higher for crops propagated using vegetative propagules, such as stems, tubers, corms, and in vitro generated plantlets, due to the simultaneous multiplication of pathogens, especially viruses, along with propagule growth [5]. The global spread of banana bunchy top virus (BBTV, genus Babuvirus, family Nanoviridae) - the causal agent of banana bunchy top disease (BBTD) - is one notorious example of a pathogen that spreads along with infected planting materials and causes widespread devastation where introduced [6].

BBTV causes severe stunting (Figure 1) and halts fruit production leading to near $100 \%$ production loss within one or two seasons in both banana and plantain (hereafter, "banana" refers to both banana and plantain) [6]. BBTV, first recognized in Fiji in the 20th century, 
has spread to about 50 countries in Africa, Asia, Australia, the South Pacific Islands and the Hawaiian Islands in the USA [6], presumably through the inadvertent movement of virus-infected suckers (shoots developed from the lateral bud of underground rhizome), which are commonly used for banana propagation. The introduced propagule serves as a source of virus acquisition and is further spread by the insect vector, banana aphid Pentalonia nigronervosa Coquerel, which is known to occur in all banana production areas around the world. In sub-Saharan Africa (SSA), BBTV was first detected in the Democratic Republic of Congo (DRC) in the 1960s [7]. The virus has since spread to all the major banana production regions in DRC and other countries in SSA [7]. The spread of virusinfected planting material was found to be the major factor for the within-country and continental spread of BBTV in SSA $[7,8]$. BBTV occurrence in Nigeria was first reported in 2012 in Idologun community in Yewa-South local government area (LGA) in Ogun State [9]. Implementation of a suite of integrated BBTD control measures, including strict controls on interstate movement of planting material enforced by the national quarantine agency, has been effective so far in containing the virus spread from Ogun State to other states of Nigeria $[8,9]$. However, the virus continues to persist within the affected areas in Ogun State and continues to serve as a major threat to the production of banana in Ogun State and Nigeria as a whole.

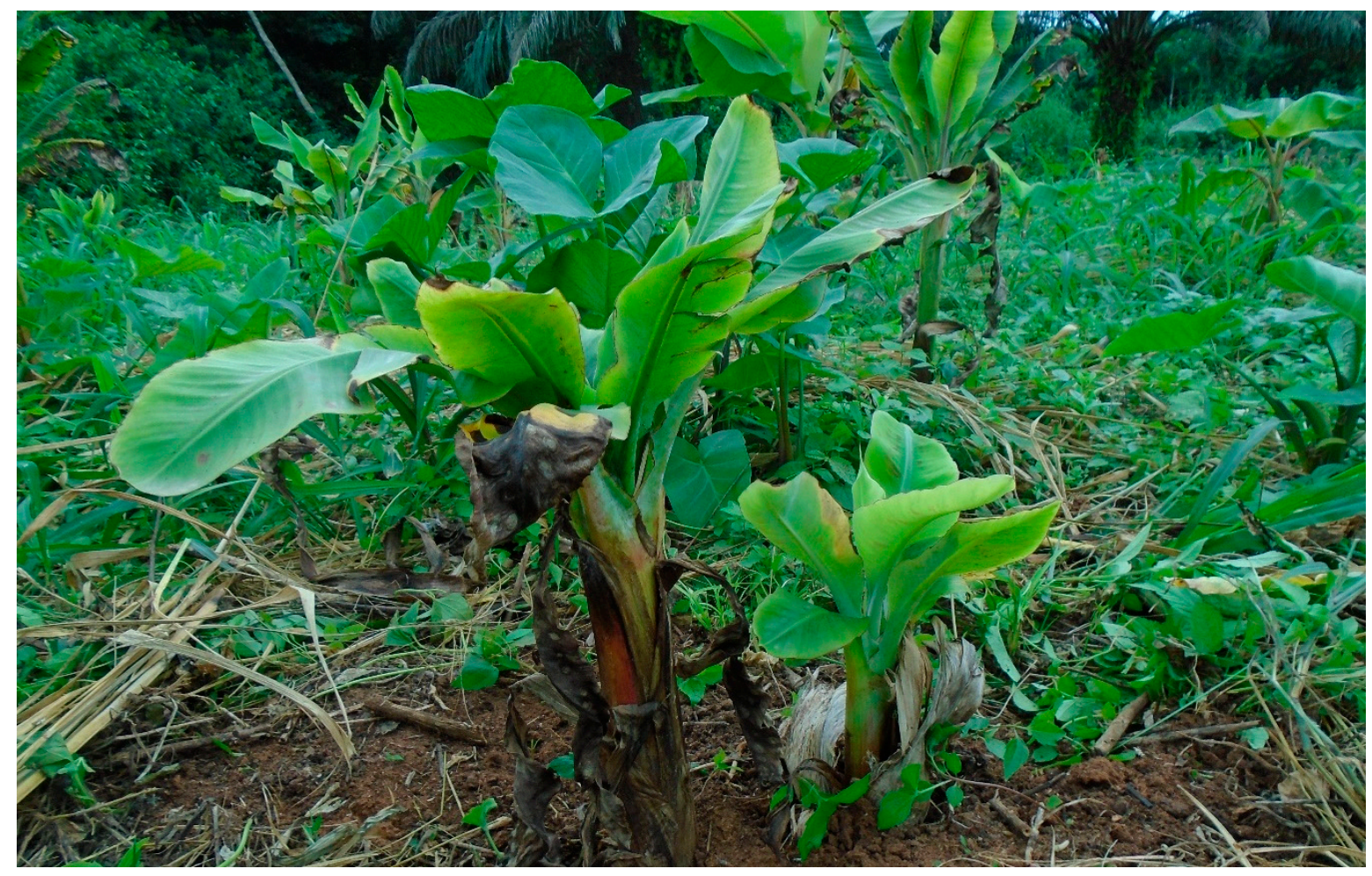

Figure 1. Severe dwarfing and bunching symptoms in Banana bunchy top virus (BBTV)-infected banana plants in Idologun, Ogun State, Nigeria (P. L. Kumar, IITA).

Banana is cultivated by vegetative propagation using suckers (for this paper, banana suckers are referred to as seeds or planting material). According to Food and Agricultural Organization (FAO) crop production data (2019), Nigeria produced about 3.18 million tons of fruit from 506,000 ha, at an average yield of $6.3 \mathrm{t} / \mathrm{ha}$. Plantain and cooking banana types are popular and widely grown throughout Nigeria as backyard plantations or in mixed cropping systems mostly by smallholder farmers with farms of less than 5 ha. Intensive production of the crop is confined to the humid forest zones, which include Akwa-Ibom, Cross River, Delta, Edo, Enugu, Imo, Lagos, Ogun, Osun, Oyo, and Rivers states. Most farmers grow the crop as semi-perennial to perennial plantations with minimum management interventions. Traditionally, farmers establish new fields with 
planting material sourced from their farms or acquired from neighbors and others as a gift or barter, or purchase within their communities [10]. This practice of sourcing suckers within and between communities is suspected to have caused the extensive spread of BBTV in the four LGAs: Ipokia, Yewa South, Yewa North, and Ifo, within Ogun State in Nigeria. Such a practice has been the norm in Nigeria and in many countries in SSA, due to the lack of an organized seed system for most vegetatively propagated crops, including banana [10].

A seed system is a multistakeholder value chain that contributes to the planting material supply for farmers. Seed systems are commonly categorized as formal and informal, depending on the process, quality, and monitoring controls used to regulate the flow of seed along the value chain, from the producer to the end-user. Generally, the formal seed system is constructed in accordance with the national seed policy and provides farmers with quality-tested seed of improved varieties. Such a formal system entails a series of activities, starting with plant breeding and ending with commercial seed sold through commercial seed producers, input dealers, and government channels under regulatory oversight [11]. In contrast, informal seed systems are based on farmer-saved seed, and cover methods of seed selection, production, and diffusion by farmers, including the exchange of seed or seeds obtained through informal networks in exchange for gifts from relatives and neighbors, barter with other farmers, or purchase from local markets [10]. The informal seed system or traditional system accounts for more than $80 \%$ of seed used and exchanged among farmers [12,13]. This informal system, however, exposes the crops to the risk of seed-borne diseases as most seeds are generally untested for health and quality [14-16].

Banana seed systems and disease management are embedded within social and gender relations; however, studies on differences in specific trait preferences as well as gender-specific research along the banana value chain are limited [17]. A few studies have shown the need for gender consideration in banana seed systems given the differences in access to and control over resources and services, social structures, and institutions in the communities [18-20]. These differences often mean that men and women face unequal constraints in seed sourcing and sharing, and this is reflected by differences in seed sourcing and sharing, including seed quantity and variety preferences $[7,21]$. Therefore, an understanding of the interactions, behavior, and decision-making among men and women in informal banana seed systems is vital to improve seed distribution, BBTD containment, and other targeted interventions.

This study focuses on determining the roles of men and women in banana seed sourcing and sharing practices in the BBTD-affected communities in Ogun State, Nigeria, compared with communities without BBTD in the neighboring Oyo State. The results are then used to understand the constraints in banana seed sourcing by men and women farmers and to discuss possible avenues of BBTD spread and options for BBTV control in Nigeria.

\section{Materials and Methods}

\subsection{Site Selection and Sampling}

The study was conducted between October and December 2017 in three communities (Idologun, Odon, and Olokuta) in BBTD-affected Yewa-South LGA in Ogun state, and three communities (Aba-paanu, Olowa, and Adejare) in Ido LGA in Oyo State which is free of BBTD (Figure 2). A survey questionnaire and focus group discussions (FGDs) were used to gather data on socioeconomic and cultural backgrounds, social networks, access to productive resources, and constraints to banana seed production and sourcing (supplementary data 1). Typically, farming activities in these communities are conducted separately by men and women. A list of banana farmers was compiled by the snowballing method, from which 50 banana farmers consisting of men and women were randomly selected in each community for interviews and FGDs. A total of 300 banana farmers, 187 men and 113 women, was interviewed. 


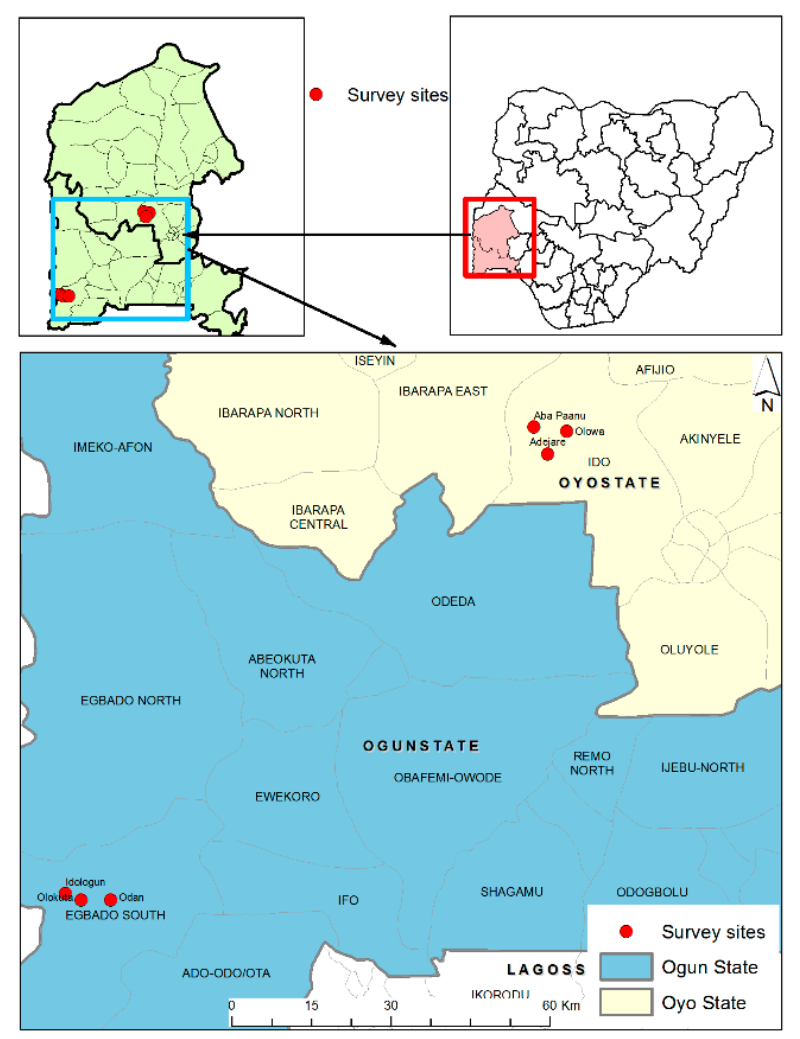

Figure 2. Map of surveyed communities in Ogun State (banana bunchy top disease (BBTD)-affected areas) and Oyo State (BBTD-free areas) in Nigeria.

\subsection{Data Collection and Data Analysis}

Quantitative data were collected through surveys of banana farmers at individual and community levels. Interviews were conducted with 150 banana farmers in BBTDaffected areas and 150 banana farmers in the unaffected areas. Qualitative data were collected through FGDs, each comprising 8-10 participants, organized separately for male and female participants in each community. Selection of participants was based on the farmer's knowledge of banana production, and cultural norms existing in the communities, especially those that would help us understand gender roles and relations in banana seed production and sourcing. FDGs were held to follow-up and to have specific interaction with farmers on themes such as banana seed production, seed sourcing and sharing behaviors within households and communities, and access to ownership of productive resources such as seed, land, and capital. Furthermore, a problem tree analysis was used as a participatory tool to highlight the challenges faced by men and women in banana seed production and sourcing.

Quantitative data were aggregated by gender and location (BBTD zone and non-BBTD zone) (supplementary data 2). The data were analyzed using descriptive statistics such as percentages and means using SPSS (Statistical Package for Social Science). FGDs were recorded, transcribed, and translated into English. The content analysis approach was used, and data were categorized into codes and classified into thematic areas. Information on banana seed sourcing and sharing behavior, and constraints in seed sourcing was analyzed to enable triangulation and validation of quantitative results.

\section{Results}

\subsection{Banana Production Characteristics}

Generally, the primary source of income in the study communities was from agricultural activities for $69.5 \%$ of men and $71.7 \%$ of women (Table 1). Banana production contributed $18.7 \%$ of income for men and $10.6 \%$ for women. When BBTD and non-BBTD areas were taken together, the mean annual income from agriculture for men (US\$1080) 
was higher than that of women (US\$754.1) (note that income data collected in Naira (N) was converted using an exchange value of N1000 $=$ US\$2.89). Over 70\% of men and women farmers in BBTD and non-BBTD areas had cultivated banana for over 20 years. Overall, men had more experience (20 years) in banana production than women (16 years). Men cultivated an average of 1.7 ha (range of $0.3-20 \mathrm{ha}$ ), while women cultivated $1.2 \mathrm{ha}$ (range of $0.3-60 \mathrm{ha})$. In the non-BBTD zone, a larger percentage of men $(87.3 \%)$ and women $(57.0 \%)$ cultivated above 1 ha, while less than $30 \%$ of men and women farmers in the BBTD zone cultivated above one hectare. In 2016, $62.9 \%$ of men and $50 \%$ of women in the BBTD zone planted more than 300 banana seeds with a mean of 391 and 307 seeds, respectively. Additionally, $76 \%$ of men and $46.8 \%$ of women in the non-BBTD zone planted more than 300 seeds with a mean of 454 and 340 seeds, respectively.

Table 1. Production characteristics of banana famers by gender in BBTD and non-BBTD areas.

\begin{tabular}{|c|c|c|c|c|c|c|}
\hline \multirow[b]{2}{*}{ Variables } & \multicolumn{2}{|c|}{ BBTD Area $(150 *)$} & \multicolumn{2}{|c|}{ Non-BBTD Area (150) } & \multicolumn{2}{|c|}{ Total (300) } \\
\hline & $\begin{array}{l}\text { Men } \\
(116)\end{array}$ & $\begin{array}{c}\text { Women } \\
\text { (34) }\end{array}$ & $\begin{array}{c}\text { Men } \\
(71)\end{array}$ & $\begin{array}{c}\text { Women } \\
\text { (79) }\end{array}$ & $\begin{array}{l}\text { Men } \\
\text { (187) }\end{array}$ & $\begin{array}{c}\text { Women } \\
\text { (113) }\end{array}$ \\
\hline \multicolumn{7}{|c|}{ Major source of income (\%) } \\
\hline Banana production & 6.9 & 5.9 & 38.0 & 12.7 & 18.7 & 10.6 \\
\hline Other agricultural activities & 77.6 & 55.9 & 56.3 & 78.5 & 69.5 & 71.7 \\
\hline Non-agricultural activities & 15.5 & 38.2 & 5.6 & 8.9 & 11.8 & 17.7 \\
\hline \multicolumn{7}{|c|}{ Estimated annual income from agriculture in US\$ $(\%)$} \\
\hline $1-500$ & 46.6 & 61.8 & 19.7 & 35.4 & 36.4 & 43.4 \\
\hline $501-1000$ & 22.4 & 20.6 & 43.7 & 45.6 & 30.5 & 38.1 \\
\hline $1001-1500$ & 12.9 & 2.9 & 19.7 & 5.1 & 15.5 & 4.4 \\
\hline $1501-2000$ & 5.2 & 8.8 & 5.6 & 11.4 & 5.3 & 10.6 \\
\hline $2001-2500$ & 5.2 & 2.9 & 4.2 & 1.3 & 4.8 & 1.8 \\
\hline$>2500$ & 7.8 & 2.9 & 7.0 & 1.3 & 7.5 & 1.8 \\
\hline Mean income from agriculture (US\$) & 1116.5 & 732.3 & 1290.9 & 813.5 & 1080.0 & 754.1 \\
\hline \multicolumn{7}{|c|}{ Years of banana cultivation $(\%)$} \\
\hline $1-10$ & 25.9 & 38.2 & 33.8 & 34.2 & 28.9 & 35.4 \\
\hline $11-20$ & 37.1 & 41.2 & 38.0 & 43.0 & 37.4 & 42.5 \\
\hline $21-30$ & 18.1 & 11.8 & 21.1 & 16.5 & 19.3 & 15.0 \\
\hline $31-40$ & 15.5 & 8.8 & 7.0 & 6.3 & 12.3 & 7.1 \\
\hline$>40$ & 3.4 & 0.0 & 0.0 & 0.0 & 2.1 & 0.0 \\
\hline Mean age (years) & 21 & 16 & 16 & 16 & 20 & 16 \\
\hline \multicolumn{7}{|c|}{ Hectares of banana farm $(\%)$} \\
\hline$\leq 1$ & 72.4 & 82.4 & 12.7 & 43.0 & 49.7 & 54.9 \\
\hline$\overline{1-3}$ & 25.9 & 17.6 & 49.3 & 48.1 & 34.8 & 38.9 \\
\hline $3-5$ & 0.9 & 0.0 & 28.2 & 6.3 & 11.2 & 4.4 \\
\hline$>5$ & 0.9 & 0.0 & 9.9 & 2.5 & 4.3 & 1.8 \\
\hline Mean farm size (ha) & 0.8 & 0.6 & 3.2 & 1.5 & 1.7 & 1.2 \\
\hline \multicolumn{7}{|c|}{ Quantity of banana seeds planted in $2016(\%)$} \\
\hline$\leq 100$ & 13.8 & 23.5 & 7.0 & 22.8 & 11.2 & 23.0 \\
\hline $100-300$ & 23.3 & 26.5 & 16.9 & 30.4 & 20.9 & 29.2 \\
\hline $300-500$ & 19.8 & 23.5 & 19.7 & 7.6 & 19.8 & 12.4 \\
\hline$>500$ & 43.1 & 26.5 & 56.3 & 39.2 & 48.1 & 35.4 \\
\hline \multicolumn{7}{|c|}{ Quantity of banana seeds harvested last season $(\%)$} \\
\hline Nil/did not harvest & 55.2 & 70.6 & 56.3 & 50.6 & 55.6 & 56.6 \\
\hline$<100$ seeds & 26.7 & 23.5 & 8.5 & 35.4 & 19.8 & 31.9 \\
\hline $100-500$ seeds & 15.5 & 2.9 & 5.6 & 10.1 & 11.8 & 8.0 \\
\hline$>500$ seeds & 2.6 & 2.9 & 29.6 & 3.8 & 12.8 & 3.5 \\
\hline Average seed harvested & 70 & 52 & 1172 & 607 & 489 & 439 \\
\hline Average seed per location & \multicolumn{2}{|c|}{66} & \multicolumn{2}{|c|}{875} & \multicolumn{2}{|c|}{473} \\
\hline
\end{tabular}


Table 1. Cont.

\begin{tabular}{|c|c|c|c|c|c|c|}
\hline \multirow{2}{*}{ Variables } & \multicolumn{2}{|c|}{ BBTD Area $(150 *)$} & \multicolumn{2}{|c|}{ Non-BBTD Area (150) } & \multicolumn{2}{|c|}{ Total (300) } \\
\hline & $\begin{array}{l}\text { Men } \\
\text { (116) }\end{array}$ & $\begin{array}{c}\text { Women } \\
\text { (34) }\end{array}$ & $\begin{array}{l}\text { Men } \\
(71)\end{array}$ & $\begin{array}{c}\text { Women } \\
\text { (79) }\end{array}$ & $\begin{array}{l}\text { Men } \\
(187)\end{array}$ & $\begin{array}{c}\text { Women } \\
\text { (113) }\end{array}$ \\
\hline \multicolumn{7}{|c|}{ Quantity of banana fruits harvested (\%) } \\
\hline 1-150 bunches & 42.2 & 50.0 & 42.3 & 35.4 & 42.2 & 39.8 \\
\hline 151-300 bunches & 21.6 & 20.6 & 38.0 & 27.8 & 27.8 & 25.7 \\
\hline 301-450 bunches & 16.4 & 17.6 & 8.5 & 17.7 & 13.4 & 17.7 \\
\hline $451-600$ bunches & 5.2 & 8.8 & 7.0 & 6.3 & 5.9 & 7.1 \\
\hline$>600$ bunches & 14.7 & 2.9 & 4.2 & 12.7 & 10.7 & 9.7 \\
\hline Average bunches harvested & 355 & 240 & 376 & 361 & 402. & 317 \\
\hline \multicolumn{7}{|c|}{ Places banana fruit is sold $(\%)$} \\
\hline On-farm (farm gate) & 1.7 & 0.0 & 14.1 & 10.1 & 6.4 & 7.1 \\
\hline Market within the community & 47.4 & 47.1 & 56.3 & 59.5 & 50.8 & 55.8 \\
\hline Market outside the community & 45.7 & 52.9 & 29.6 & 27.8 & 39.6 & 35.4 \\
\hline Market within and outside the community & 5.2 & 0.0 & 0.0 & 2.5 & 3.2 & 1.8 \\
\hline
\end{tabular}

* All values in brackets are number of farmers.

Both men and women farmers were involved in seed harvesting; however, only a small proportion of the farmers interviewed had harvested banana planting material in 2016. Men harvested an average of 489 banana suckers, while women harvested an average of 439 suckers. An average of 875 banana suckers was harvested in the non-BBTD zone compared with an average of 66 banana suckers in the BBTD zone. In terms of harvesting banana fruits, overall, $70 \%$ of men and $65.5 \%$ of women harvested 300 banana fruit bunches. The average number of fruit bunches harvested in the BBTD zone by men and women farmers was 355 and 240, respectively, while in the non-BBTD zone, men and women farmers harvested 376 and 361 banana fruit bunches, respectively. Overall, 50.8\% of men and $55.8 \%$ of women farmers sold harvested fruit bunches within the community, while $39.6 \%$ of men and $35.4 \%$ of women sold their produce outside the community.

\subsection{Banana Seed Sourcing among Farmers}

Banana seed sourcing revealed that farmers acquired planting material from several sources for establishing new plantations (Table 2; Figure 3). In total, a higher percentage of men sourced seeds from their own old fields $(33.7 \%)$ and from neighbors $(20.3 \%)$, while women sourced seeds from relatives (43.4\%) and neighbors (20.4\%). In BBTD and nonBBTD areas, women sourced seeds more from relatives (36.6\%) and neighbors $(48.1 \%)$, while men sourced more seeds from old fields (39.7\%) and neighbors (36.6\%). Responses from FGDs emphasize that seed sourcing practices differ among men and women farmers.

Table 2. Characteristics of banana seeds sourcing by gender in BBTD and non-BBTD areas.

\begin{tabular}{|c|c|c|c|c|c|c|}
\hline \multirow[b]{2}{*}{ Seed Sourcing } & \multicolumn{2}{|c|}{ BBTD Areas $(150 *)$} & \multicolumn{2}{|c|}{ Non-BBTD Areas (150) } & \multicolumn{2}{|c|}{ Total (300) } \\
\hline & $\begin{array}{l}\text { Men } \\
\text { (116) }\end{array}$ & $\begin{array}{c}\text { Women } \\
\text { (34) }\end{array}$ & $\begin{array}{c}\text { Men } \\
\text { (71) }\end{array}$ & $\begin{array}{c}\text { Women } \\
(79)\end{array}$ & $\begin{array}{l}\text { Men } \\
(187)\end{array}$ & $\begin{array}{c}\text { Women } \\
\text { (113) }\end{array}$ \\
\hline \multicolumn{7}{|c|}{ Location of sourced banana seeds } \\
\hline Within the community & 81.0 & 73.5 & 87.3 & 96.2 & 83.4 & 89.4 \\
\hline Outside the community & 19.0 & 26.5 & 12.7 & 3.8 & 16.6 & 10.6 \\
\hline \multicolumn{7}{|c|}{ Preferred traits in banana seed sourcing } \\
\hline Fruit size of mother plant & 39.7 & 47.1 & 29.6 & 21.5 & 35.8 & 33.6 \\
\hline Height of mother plant & 19.8 & 14.7 & 29.6 & 36.7 & 23.5 & 30.1 \\
\hline Appearance/size of seed & 21.6 & 17.7 & 33.8 & 40.5 & 26.2 & 27.4 \\
\hline Large green leaves of plant & 14.7 & 11.7 & 7.0 & 1.3 & 11.8 & 5.3 \\
\hline Disease-free seed & 4.2 & 8.8 & 0.0 & 0.0 & 2.7 & 3.6 \\
\hline
\end{tabular}

* All values in brackets are number of farmers. Note: All figures are in percentages. 


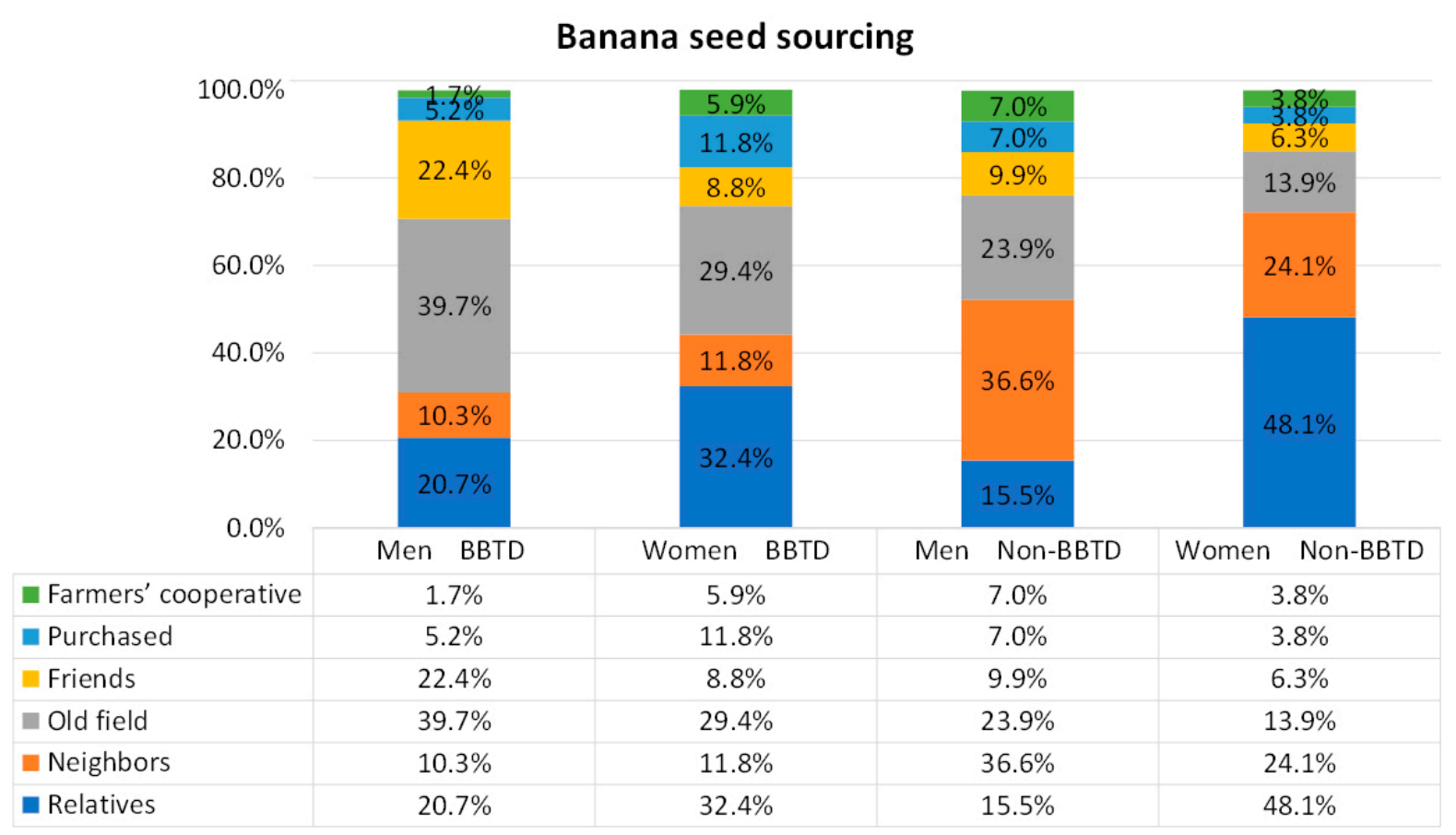

Figure 3. Banana seeds sourcing by men and women farmers in BBTD and non-BBTD areas.

"It is in banana production I was born, that is where I grew up. My parents were farmers, they cultivated cocoa and banana. It was from my fathers' farm, that I got my first seed. Sometimes I source seeds from co-farmers. If I see a variety that I like, I can just walk into the farm to take it or request seeds and I will be given." (Idologun men FGD, BBTD area)

"We often get seeds from our husband or other close relatives. We as women, we are restricted culturally from entering a stranger's field especially if he is a man. There is a law that one must never enter someone's farm apart from your husband's farm to harvest suckers without prior notice or without asking the owners or taking permission. If such happened, one will be taken to the palace and get punished." (Odon women, FGD, BBTD area)

\subsection{Preferred Traits in Banana Seed Sourcing and Sharing}

Farmers often sourced banana seed within the community (Table 3, Figure 4). The majority of men $(81.0 \%)$ and women farmers $(73.5 \%)$ in the BBTD area sourced their first seed within their communities. Similarly, in the non-BBTD area, $87.3 \%$ of men and $96.2 \%$ of women sourced their first seed within their communities. Fruit size of the mother plant was the most important trait for $35.8 \%$ of men and $33.6 \%$ of women, while the size of the mother plant was preferred by $23.5 \%$ of men and $30.1 \%$ of women.

Banana seeds were shared within the communities by men $(70.6 \%)$ and women farmers (76.1\%), while $22.5 \%$ and $16.8 \%$ of men and women farmers, respectively, shared seeds within and outside the community. Both in BBTD and non-BBTD areas, $87.1 \%$ of men and $89.0 \%$ of women shared banana seeds as gifts with $78.7 \%$ of men and $82.6 \%$ of women farmers getting nothing in exchange, while a few exchanged banana seeds for money and farm labor. Men shared banana seeds with relatives (36.9\%) and neighbors (23.5\%), while women shared seeds with neighbors $(31.0 \%)$ and relatives $(30.1 \%)$ (Figure 3$)$. The disaggregated results reveal that in the BBTD and non-BBTD areas, banana seeds were mostly shared among relatives, friends, and neighbors by men and women farmers. 
Table 3. Banana seed sharing characteristics by gender in BBTD and non-BBTD areas.

\begin{tabular}{|c|c|c|c|c|c|c|}
\hline \multirow[b]{2}{*}{ Seed Sharing Characteristics } & \multicolumn{2}{|c|}{ BBTD Area $(150 *)$} & \multicolumn{2}{|c|}{ Non-BBTD Area (150) } & \multicolumn{2}{|c|}{ Total (300) } \\
\hline & $\begin{array}{l}\text { Male } \\
(116)\end{array}$ & $\begin{array}{c}\text { Female } \\
\text { (34) }\end{array}$ & $\begin{array}{c}\text { Male } \\
(71)\end{array}$ & $\begin{array}{c}\text { Female } \\
\text { (79) }\end{array}$ & $\begin{array}{l}\text { Male } \\
(187)\end{array}$ & $\begin{array}{c}\text { Female } \\
\text { (113) }\end{array}$ \\
\hline \multicolumn{7}{|l|}{ Location where seeds are shared } \\
\hline Within the community & 62.1 & 61.8 & 84.5 & 82.3 & 70.6 & 76.1 \\
\hline Outside the community & 6.0 & 11.8 & 8.5 & 5.1 & 7.0 & 7.1 \\
\hline \multicolumn{7}{|l|}{ Motivation for sharing seeds } \\
\hline Gift & 88.9 & 95.5 & 84.3 & 87.0 & 87.1 & 89.0 \\
\hline To avoid extinction & 8.6 & 4.5 & 2.0 & 5.80 & 6.1 & 5.5 \\
\hline Exchange for other products & 2.5 & 0 & 7.8 & 4.3 & 4.5 & 3.3 \\
\hline Pay debts & 0 & 0 & 5.9 & 2.9 & 2.3 & 2.2 \\
\hline \multicolumn{7}{|l|}{ Exchange for banana seeds } \\
\hline Nothing & 76.8 & 84.0 & 82.4 & 82.0 & 78.7 & 82.6 \\
\hline Banana seeds in future & 6.1 & 4.0 & 0 & 8.2 & 4.0 & 7.0 \\
\hline Money & 0 & 0 & 15.7 & 6.6 & 5.3 & 4.7 \\
\hline Assistance & 15.2 & 8.0 & 2.0 & 1.6 & 10.7 & 3.5 \\
\hline Other crop seed & 2.0 & 4.0 & 0 & 1.6 & 1.3 & 2.3 \\
\hline
\end{tabular}

* All values in brackets are number of farmers. Note: All figures are in percentages.

\section{Banana seed sharing}

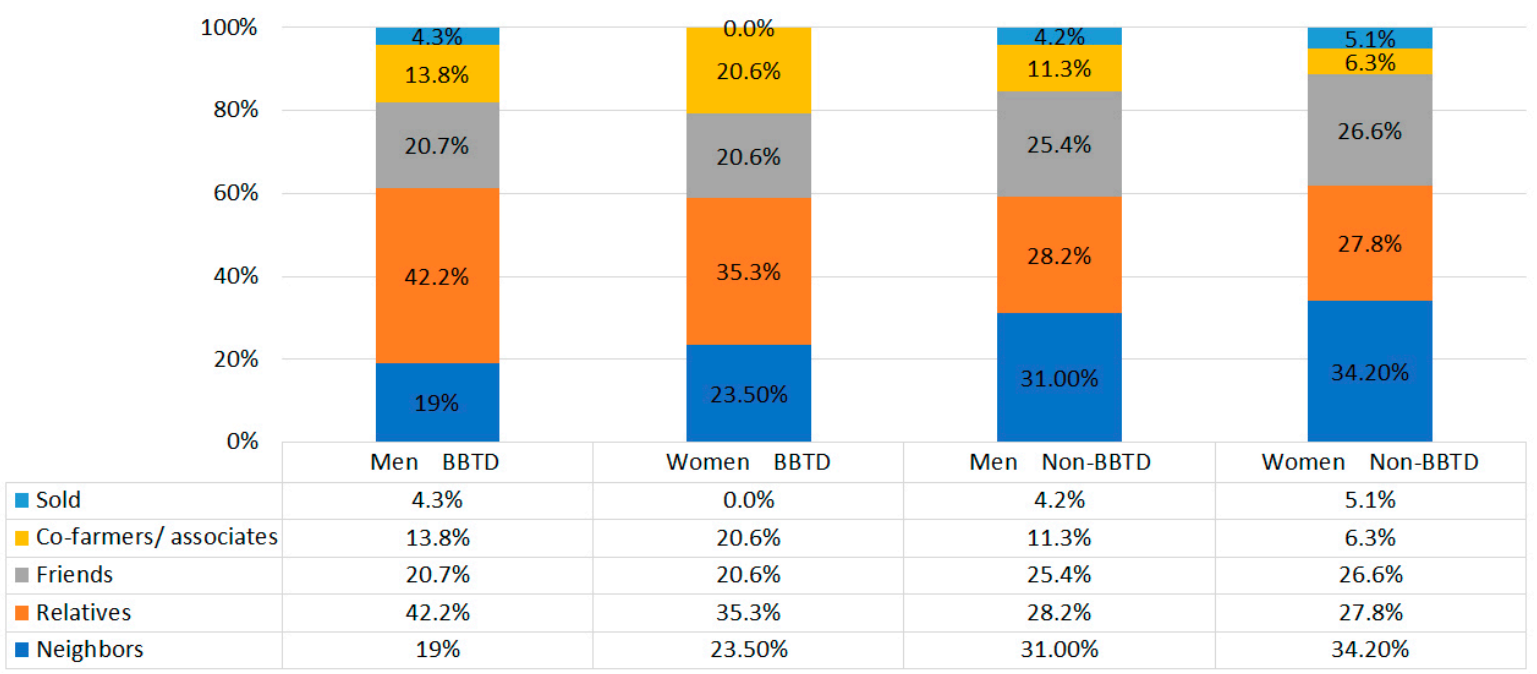

Figure 4. Banana seed sharing by men and women farmers in BBTD and non-BBTD areas.

\subsection{Constraints in Banana Seed Sourcing}

Several constraints were encountered in banana seed sourcing, which were differentiated by gender and location (Table 4). Transport was a main problem for men (39.9\%) and women (45.6\%) farmers in BBTD-affected and unaffected areas. Seed infection by diseases (black sigatoka, BBTD) and pests (weevils, nematodes) was mentioned as a constraint by $6.3 \%$ of the men, but none of the women, in BBTD-affected areas. Overall, about $5.5 \%$ of men and women farmers indicated diseases and pests, which suggest a very low level of awareness. Other constraints to banana seed sourcing were unavailability of seed in large quantity and physical stress due to the bulky nature of seeds. According to the FGDs, farmers had limited knowledge of BBTD given that it is a relatively new disease, and many were unaware of its implications and disguising characteristics. The disaggregated results across study locations revealed that in the BBTD area (Ogun State), long-distance seed sourcing was more of a constraint to women $(65.4 \%)$ than for men $(42.7 \%)$, while in the 
non-BBTD area, the high cost of transportation of seeds to the farm was more of a constraint to men $(40.4 \%)$ than women $(28.3 \%)$.

"Sometimes we get suckers (banana seeds) from long-distance farms, and due to the weight, we cannot trek with them, so we often need a means of transportation which is always too expensive and sometimes unaffordable." (Olokuta, women FGD, NonBBTD area)

Table 4. Constraints in banana seed sourcing by gender in BBTD and non-BBTD areas.

\begin{tabular}{|c|c|c|c|c|c|c|}
\hline \multirow[b]{2}{*}{ Constraints } & \multicolumn{2}{|c|}{ BBTD Area $(150 *)$} & \multicolumn{2}{|c|}{ Non-BBTD Area (150) } & \multicolumn{2}{|c|}{ Total (300) } \\
\hline & $\begin{array}{l}\text { Men } \\
\text { (116) }\end{array}$ & $\begin{array}{c}\text { Women } \\
\text { (34) }\end{array}$ & $\begin{array}{c}\text { Men } \\
(71)\end{array}$ & $\begin{array}{c}\text { Women } \\
\text { (79) }\end{array}$ & $\begin{array}{l}\text { Men } \\
(187)\end{array}$ & $\begin{array}{c}\text { Women } \\
\text { (113) }\end{array}$ \\
\hline Long distance from source & 42.7 & 65.4 & 34.6 & 35.8 & 39.9 & 45.6 \\
\hline High cost of seed transport to farm & 7.3 & 7.7 & 40.4 & 28.3 & 18.9 & 21.5 \\
\hline Disease infection of seed & 6.3 & 0 & 3.8 & 7.5 & 5.4 & 5.1 \\
\hline High prices of seed & 2.1 & 7.7 & 9.6 & 3.8 & 4.7 & 5.1 \\
\hline Unavailability of seed in large quantity & 7.3 & 3.8 & 0 & 0 & 4.7 & 1.3 \\
\hline Stress due to bulky nature of seed & 2.1 & 0 & 0 & 1.9 & 1.4 & 1.3 \\
\hline Inadequate knowledge of harvesting seed & 2.1 & 0 & 0 & 0 & 1.4 & 0 \\
\hline
\end{tabular}

* All values in brackets are number of farmers. Note: All figures are in percentages.

\section{Discussion}

In most farming communities, formal and informal rules influence the ability of men and women to access quality seed differently [4]. Men farmers sourced their first seeds from old fields because they often inherited banana fields from their fathers, and women farmers sourced more of their first seeds from relatives, especially husbands, because culturally it is considered inappropriate for women to source seeds from strangers and distant places. Similar studies in Cameroon and Burundi showed that both men and women sourced banana seeds from their established fields. According to Nkengla-Asi et al. [20], women source seeds both for their fields and those of their husbands since this was considered as a characteristic of the "good wife" in those communities. A study by Ajambo et al. [7] on banana seed systems and production in nine SSA countries (Benin, Burundi, Cameroon, Congo Brazzaville, Democratic Republic of Congo (DRC), Gabon, Malawi, Nigeria, and Uganda) revealed that farmers primarily source seed through exchange of seeds among themselves for cash or services, as well as from local markets. Overall, $96 \%$ of the households in the study communities sourced planting materials from their own fields (70\%) or neighbors' fields $(26 \%)$. Seed purchase from commercial vendors formed a minor part of the seed sourcing activities. The purchase of planting materials is influenced by gender as men are more likely than woman to pay to procure planting materials.

In many rural communities in Nigeria, farms are generally willed to the male offspring. The patriarchal power structure favors men in allocating productive resources within the household [18,22]. A study in Cameroon indicated that men have more access to and control of productive resources such as land than women, and that men are more likely to buy clean seed if sold than women who predominantly used informal seed sharing sources [20]. Similar to seed sourcing, the sharing of banana seeds within the communities was through social networks in exchange for gifts from relatives and neighbors, through bartering with other farmers, or purchasing from local markets [4]. Seeds are rarely sold and often given as gifts to relatives, neighbors, and friends, likely due to small farm holdings and active social networks among community members. Smallholder farmers usually need small quantities of planting material, and obtain these within the informal seed system $[4,15,23]$.

The sharing and sourcing of banana seeds along social networks strengthen communal ties and prevent the extinction of seeds. Hence, seeds are continually available to farmers for little or no cost within the community. Even on rare occasions when bought, these 
seeds are often bought along social ties. These observations on banana seed sourcing in Nigeria are similar to those for potato seed sourcing in Malawi, where selling and buying of potato seed depends on trust and ties [24]. This exchange (give and take) of banana seeds among farmers within the communities increases farmer access to seed, even for those with limited purchasing power, as little or nothing is spent purchasing seeds. The acquisition of inputs through non-cash alternatives, as in the informal sector, is preferred by small-scale farmers who have limited cash $[10,15]$. However, the exchange of seeds along social ties predisposes women, widows, youth, and other vulnerable groups to the risk of getting fewer seeds or seed of less preferred varieties and possibly lower quality. There is often a substantial gap between supply and demand, when the demand is high, especially for large quantities of preferred varieties [25].

The shortage of seeds often results in higher transportation costs as farmers have to travel to other communities, delayed and reduced planting, and sometimes farmer illness due to increased stress. The constraints in banana seed sourcing are exacerbated by the vegetatively propagated nature of banana, i.e., low multiplication ratio, bulkiness, short shelf life, and difficulties in maintenance, especially during the dry season [21]. Along gender lines, women are most affected by these constraints because, in most communities, they are not allowed to enter men's farms; they hardly have access to motorized transport, and often have to trek long distances in search of seeds. A study in Nigeria and Kenya on gender mobility in public spaces showed that women generally are less mobile than men due to norms that limit the spaces they can visit as well as the purpose, duration, and time of day of their travels [25]. Hence, women often have to settle for less-preferred seeds and cultivate smaller farm sizes to cope with their productive and reproductive roles at home [26]. In terms of preferred seed varieties, there is minimal difference between men and women as both prefer varieties based on large finger size and traditional household uses. Male farmers in Nigeria are responsible for banana seed harvesting due to the energy and traditional norms involved in harvesting. Most women only assist their husbands to transport the harvested seeds to their new fields. However, some women harvested banana seeds by themselves, especially when they have no one to assist and cannot afford labor. In banana production, men harvested a greater number of banana planting material, and cultivated larger farms than women. Men are often more involved in production (cultivation), while women market the fruits [27].

The land tenure system practiced in most communities in Nigeria favors men over women [28]. Predominately, land accessed by inheritance is often exclusively for males. Hence, most women depend on their husbands for agricultural land. Differentiated gender roles are thus manifested in social rights and entitlements that does not grant equal economic and political opportunities for women, and in particular, deny women the right to own land [28-30]. This means that women have less access to land for agricultural purposes.

Banana seed sharing behaviors in BBTD-affected and non-affected communities are quite similar. In both communities, banana seeds are sourced informally, relying mostly on social networks such as neighbors and relatives, and old fields. This lack of difference was linked to the lack of awareness of pests and diseases, and the significance of quality and health of planting material. Generally, farmers attribute plant diseases to a curse from God. This finding corroborates results from earlier studies $[7,20]$ which also revealed that farmers focus on quantity over quality during seed sourcing due to poor awareness. This observation explains the persistence of BBTD within the affected LGAs in Ogun State, as farmers tend to reestablish fields using infected suckers. Various efforts have been initiated to raise awareness about BBTD among farmers and the benefits of using suckers from healthy planting materials $[6,8]$. Efforts are also being enhanced to establish the local production of clean planting material of farmer-preferred varieties with BBTV-free seed sources.

Informal seed sources (farmer seed networks) serve a crucial role in ensuring seed access. A study in Africa indicated that about $90 \%$ of farmers access their seed from 
informal systems with 50.9\% from local markets [15]. Informal sharing patterns are linked to social ties. It is no surprise that cultivated farm size and planted and harvested banana seeds in non-affected BBTD areas are higher than in the BBTD-affected areas. However, it is important to ensure that the growers in the BBTD-free areas are aware of the nature of the disease and management measures that can prevent/limit its spread if it gets into the community. Informal seed sharing patterns between men and women in the communities could exacerbate the spread of BBTD if they are not aware of BBTD symptoms and containment measures. Being both seed- and vector-borne, BBTD quickly limits the production and availability of clean seed in an area. When plants are infected by the virus, they become progressively stunted and ultimately stop producing fruits at the late stage [31]. Farmers often regard BBTD-affected plants as suckers and harvest them for use as planting material; hence, BBTD is transmitted inadvertently into new fields/areas.

In the communities examined in this study, cultural methods of seed cleaning exist for true seed crops (e.g., washing of seeds in wood ash to kill insect pests) as well as clonal crops (e.g., sourcing of seed from healthy-looking plants). In the case of BBTD, farmers lack knowledge of the disease as it is a new incursion in the region, and they are prone to mistake BBTD-affected plants as young suckers and harvest them for replanting in another location. Awareness about the disease is a crucial requirement to mitigate the disease spread in Nigeria. Collaborations and alliances with local partners have been established to sensitize farmers about disease symptoms, mode of its spread, and importance of using clean planting material by the International Institute of Tropical Agriculture (IITA), together with national programs such as the Nigerian Agricultural Quarantine Services (NAQS) and the National Horticultural Research Institute (NIHORT), through initiatives such as the CGIAR Roots, Tubers and Bananas (CRP-RTB) Alliance for the control of BBTV in Africa (www.bbtvalliance.org (accessed on 7 March 2021)), and the "BBTV Mitigation: Community Management in Nigeria", led by the University of Queensland in collaboration with NIHORT and IITA and as partners.

The BBTD control methods established in the communities include awareness creation about disease symptoms and control measures, and the establishment of banana-free zones or fallows for a minimum of three months to eliminate aphid vectors, and monitoring of banana re-sprouting and aphid occurrence during banana-free fallows. Other control methods include establishing buffer zones between new and infected banana fields, monitoring newly planted banana fields to detect infection, and strict regulatory control on the movement of planting material from disease-affected areas to unaffected areas. Both men and women banana farmers should be targeted in the interventions for effectiveness and efficiency in BBTD management to stop further spread of the disease. Addressing issues such as participation, access, control, norms, and values help to identify specific challenges and opportunities for men and women found in the affected communities and countries and provide entry points for targeted interventions and sustainable management [15,32]. Containment of BBTD spread and banana production recovery in the disease-affected communities requires a socially inclusive approach with the engagement of several actors and partners, and an in-depth understanding of the physical, social, and cultural environments as well as gender relations and norms within and between households, communities, and countries.

\section{Conclusions}

The study identified gender-differentiated roles, responsibilities, and choices in banana seed selection, sourcing, and distribution between men and women within two sets of communities in Nigeria. Both men and women exchange seed predominantly within the communities, whereas men are mostly involved in introducing seed from far-off places (long-distance movement). The existing seed sourcing practices of both women and men farmers heighten the risk of disease spread through planting materials within the communities. However, the risk of BBTD introduction into communities is higher in the 
seed sourcing activities of men because of their role in long-distance movement of seed, which often contributes to the wide dissemination of seed-transmitted diseases $[7,8]$.

Awareness-raising on the potential spread of diseases through sourcing and sharing of infected seeds should consider gender-differentiated roles and social practices to reduce the spread of BBTD along with disease-free planting material within the communities. A reliable, clean seed supply system is crucial for the sustainable management of BBTD and recovery of BBTD-affected communities [15]. The research community and extension agencies should use participatory approaches in field-level activities that engage all stakeholders in management interventions to ensure that the BBTD-free areas continue to remain free of the disease.

Informal seed systems are vital for seed security in agricultural communities. BBTD spread can be managed through initiatives that actively support local seed quality and farmer-to-farmer networks. This will ensure that farmers have access to clean seeds through monitoring and strict regulatory control on the movement of planting material from disease-affected to unaffected areas. National and local governments in collaboration with research institutes, farmer groups, and NGOs should facilitate the supply of clean seeds to farmers. Strategic partnerships through collaboration and alliances are essential for the effective management of the disease at community, regional, and global levels.

Supplementary Materials: The following are available online at https:/ / www.mdpi.com/2071-105 0/13/6/3310/s1, Data 1: Household Questionnaire for information on banana seed sourcing and sharing by farmers in Nigeria; Data 2: Anonymized data set of sourcing and sharing of banana planting material in communities with and without banana bunchy top disease in Nigeria.

Author Contributions: Conceptualization, L.N.-A. and P.L.K.; methodology, L.N.-A., P.L.K., and R.H.; investigation and formal analysis, F.E., T.A.L., O.O., L.N.-A., Amah D.A., P.L.K.; writingoriginal draft preparation, L.N.-A., F.E. and P.L.K.; writing-review and editing, all authors; supervision, L.N.-A., P.L.K. and R.H.; funding acquisition, P.L.K. and R.H. All authors have read and agreed to the published version of the manuscript.

Funding: This research was undertaken as part of the ALLIANCE for BBTV Control in Africa (BA3.4) managed by the International Institute of Tropical Agriculture (IITA), funded by the CGIAR Research Program on Roots, Tubers and Bananas (RTB) and supported by CGIAR Trust Fund contributors; and the University of Queensland Project on BBTV mitigation in Nigeria (OPP1130226), supported by the Bill \& Melinda Gates Foundation (BMGF). The BMFG also supported the open access publication fees (OPP1130226).

Institutional Review Board Statement: Survey questionnaire was reviewed and approved for use.

Informed Consent Statement: Informed consent was obtained from all subjects involved in the study.

Data Availability Statement: Summarized data included as supplementary table.

Acknowledgments: Authors would like to thank T Oviasuyi of the IITA Virology Unit for technical support in field surveys, Aman Omondi (Bioversity International) for review of the first draft of the manuscript, and Tunrayo Alabi of IITA's GIS Unit for preparing the geographic map. Authors would also like to thank the two anonymous reviewers and the editor for valuable inputs in finalizing this manuscript.

Conflicts of Interest: The authors declare no conflict of interest.

\section{References}

1. Thijssen, M.H.; Bishaw, Z.; Beshir, A.; de Boef, W.S. Farmers, Seeds and Varieties: Supporting Informal Seed Supply in Ethiopia; Wageningen International: Wageningen, The Netherlands, 2008; p. 348.

2. Pautasso, M.; Aistara, G.; Barnaud, A.; Caillon, S.; Clouvel, P. Seed exchange networks for agro-biodiversity conservation, a review. Agron. Sustain. Dev. 2012, 33, 151-175. [CrossRef]

3. Muthoni, J.; Nyamongo, D.O. Seed system in Kenya and their relationship to on-farm conservation of food crops. J. New Seeds 2008, 9, 330-342. [CrossRef]

4. Mudege, N.N.; Walsh, S. Gender and roots tubers and bananas seed systems: A literature review. In CGIAR Research Program on Roots, Tubers and Bananas (RTB); RTB Working Paper No. 2016-2; RTB-CIP: Lima, Peru, 2016; p. 26, ISSN 2309-6586. 
5. Kumar, P.L.; Curevo, M.; Kreuze, J.F.; Muller, G.; Kulkarni, G.; Kumari, S.G.; Massart, S.; Mezzalama, M.; Alakonya, A.; Muchugi, A.; et al. Phytosanitary interventions for safe global germplasm exchange and prevention of transboundary pest spread: The role of CGIAR germplasm health units. Plants 2021, 10, 328. [CrossRef] [PubMed]

6. Kumar, P.L.; Selvarajan, R.; Iskra-Caruana, M.-L.; Chabannes, M.; Hanna, R. Biology, etiology and control of virus diseases of banana and plantain. Adv. Virus Res. 2015, 91, 229-269.

7. Kumar, P.L.; Hanna, R.; Alabi, O.J.; Soko, M.M.; Oben, T.T.; Vangue, G.H.P.; Naidu, R.A. Banana bunchy top virus in sub-Saharan Africa: Investigations on virus distribution and diversity. Virus Res. 2011, 159, 171-182. [CrossRef] [PubMed]

8. Ajambo, S.; Rietveld, A.; Nkengla, L.W.; Niyongere, C.; Dhed'a, D.B.; Olaosebikan, D.O.; Nitunga, E.; Toengaho, J.; Kumar, P.L.; Hanna, R.; et al. Recovering banana production in bunchy top-affected areas in sub-Saharan Africa: Developing gender-responsive approaches. Acta Hortic. 2018, 1196, 219-228. [CrossRef]

9. Adegbola, R.A.; Ayodeji, O.; Awosusi, O.O.; Atiri, G.I.; Kumar, P.L. First report of banana bunchy top disease caused by Banana bunchy top virus in banana and plantain (Musa spp.) in Nigeria. Plant Dis. 2013, 97, 290. [CrossRef]

10. Almekinders, C.J.M.; Walsh, S.; Jacobsen, K.S.; Andrade-Piedra, J.L.; McEwan, M.; de Haan, S.; Kumar, P.L.; Staver, C. Why interventions in the seed systems of roots, tubers and bananas crops do not reach their full potential. Food Secur. 2019, 11, 23-42. [CrossRef]

11. Louwaars, N.P.; de Boef, W.S. Integrated seed sector development in Africa: A conceptual framework for creating coherence between practices, programs, and policies. J. Crop. Imp. 2012, 26, 39-59. [CrossRef]

12. Biemond, C.P.; Stomph, T.J.; Kamaraa, A.; Abdoulaye, T.; Hearne, S.; Struik, P.C. Are investments in an informal seed system for cowpea a worthwhile endeavour? Int. J. Plant Prod. 2012, 6, 367-386.

13. Almekinders, C.J.M.; Louwaars, N.P. The importance of the farmers' seed systems in a functional national seed sector. J. New Seeds 2002, 4, 15-33. [CrossRef]

14. Ortiz, O.; Pérez, W.; Orrego, R.; Pradel, W.; Tenorio, J.; Andrade-Piedra, J.L.; Schulte-Geldermann, E.; Schultz, S.; Demo, P.; Kakuhenzire, R.; et al. Qualitative model of potato seed systems in developing countries: An attempt to converge seed-related biophysical and socioeconomic factors. In Proceedings of the Paper presented at the 16th International Symposium of the ISTRC held in Ogun State, Abeokuta, Nigeria, 23-28 September 2012.

15. McGuire', S.J.; Sperling, L. Seed systems smallholder farmers use. Food Secur. 2016, 8, 179-195. [CrossRef]

16. Bentley, J.W.; Andrade-Piedra, J.L.; Demo, P.; Dzomeku, B.; Jacobsen, K.; Kikulwe, E.; Kromann, P.; Kumar, P.L.; McEwan, M.; Mudege, N.; et al. Understanding root, tuber, and banana seed systems and coordination breakdown: A multi-stakeholder framework. J. Crop. Impr. 2018, 32, 599-621. [CrossRef]

17. Marimo, P.; Caron, C.; Van den Bergh, I.; Crichton, R.; Weltzien, E.; Ortiz, R.; Tumuhimbise, R. Gender and trait preferences for banana cultivation and use in Sub-Saharan Africa: A Literature Review. Econ. Bot. 2020, 74, 226-241. [CrossRef]

18. Teeken, B.; Olaosebikan, O.; Haleegoah, J.; Oladejo, E.; Madu, T.; Bello, A.; Parkes, E.; Egesi, C.; Kulakow, P.; Kirscht, H.; et al. Cassava trait preferences of men and women farmers in Nigeria: Implications for breeding. Econ. Bot. 2018, 72, $263-277$. [CrossRef]

19. Doucet, A. There's a huge gulf between me as a male career and women: Gender, domestic responsibility, and the community as an institutional arena. Community Work Fam. 2000, 3, 163-184. [CrossRef]

20. Nkengla-Asi, L.; Omondi, A.B.; Simo, V.C.; Assam, E.; Ngatat, S.; Boonabaana, B. Gender dynamics in banana seed systems and impact on banana bunchy top disease recovery in Cameroon. Outlook Agric. 2020, 49, 235-244. [CrossRef]

21. Kilwinger, F.B.; Marimo, P.; Rietveld, A.M.; Almekinders, C.J.; van Dam, Y.K. Not only the seed matters: Farmers' perceptions of sources for banana planting materials in Uganda. Outlook Agric. 2020, 49, 119-132. [CrossRef] [PubMed]

22. Galie, A.; Jiggins, J.; Struick, P.C. Women's identity as farmers: A case study from ten households in Syria. NJAS Wagening. J. Life Sci. 2013, 64-65, 25-33. [CrossRef]

23. Badstue, L.B.; Bellon, M.R.; Berthaud, J.; Ramírez, A.; Flores, D.; Juárez, O. The dynamics of farmers' maize seed supply practices in the central valleys of Oaxaca, Mexico. World Dev. 2007, 35, 1579-1593. [CrossRef]

24. Mudege, N.N.; Kapalasa, E.; Chevo, T.; Nyekanyeka, T.; Demo, P. Gender norms and the marketing of seeds and ware potatoes in Malawi. J. Gend. Agric. Food Sec. 2015, 1, 18-41.

25. Lodin, J.B.; Tegbaru, A.; Bullock, R.; Degrande, A.; Nkengla, L.W.; Gaya, H.I. Gendered mobilities and immobileities: Women's and men's capacities for agricultural innovation in Kenya and Nigeria. Gend. Place Cult. 2019, 26, 1759-1783. [CrossRef]

26. Nkengla-Asi, L.; Olaosebikan, O.D.; Che, V.S.; Ngatat, S.; Zandjanakou-Tachin, M.; Hanna, R.; Kumar, P.L. Gender norms and their implications for banana production and recovery in West Africa. In Gender and Practice: Knowledge, Policy, Organizations Advances in Gender Research; Emerald Publishing Limited: Bingley, UK, 2020; Volume 28, pp. 61-75.

27. Fapohunda, T.M. Gender and development: Challenges to women involvement in Nigeria's development. Int. J. Acad. Res. Bus. Soc. Sci. 2012, 2, 14-28.

28. Cauthen, J.; Jones, D.; Gugerty, M.K.; Anderson, L. Banana and Plantain Value Chain: West Africa (Evans School of Policy Analysis and Research (EPAR), 2013, Brief No. 239. Available online: https://evans.uw.edu/sites/default/ (accessed on 7 March 2021).

29. Ajala, T. Gender discrimination in land ownership and the alleviation of women's poverty in Nigeria A call for new equities. Int. J. Discrim. Law 2017, 17, 51-66. [CrossRef] 
30. Ebeku, K.S.A. A new dawn for African women? Prospects of Africa's protocol on women's rights. Sri. Lanka J. Int. Law 2004, $16,83$.

31. Ngatat, S.; Hanna, R.; Kumar, P.L.; Gray, S.M.; Cilia, M.; Ghogomu, R.T.; Fontem, D.A. Relative susceptibility of Musa genotypes to banana bunchy top disease in Cameroon and implication for disease management. Crop. Prot. 2017, 101, 116-122. [CrossRef]

32. McEwan, M.A.; Almekinders, C.J.M.; Andrade-Piedra, J.L.; Delaquis, E.; Garrett, K.A.; Kumar, P.L.; Mayanja, S.; Omondi, B.A.; Rajendran, S.; Thiele, G. "Breaking through the 40\% adoption ceiling: Mind the seed system gaps." A perspective on seed systems research for development in One CGIAR. Outlook Agric. 2021, 1-8. [CrossRef] 